\title{
Antioxidant Activity, Microbiological Quality, and Acceptability of Spontaneously Fermented Shrimp Sausage (Litopenaeus vannamei)
}

\author{
Diana N. Afifah $\left(\mathbb{D},{ }^{1,2}\right.$ Uchida T. S. Dewi ${ }^{1},{ }^{1}$ Rizka D. Anggraeni ${ }^{1},{ }^{1}$ A. Fahmy A. Tsani ${ }^{1},{ }^{1,2}$ \\ Nurmasari Widyastuti $\left(\mathbb{D},{ }^{1,2}\right.$ Faizah Fulyani ${ }^{D}{ }^{3}$ and Gemala Anjani ${ }^{1,2}$ \\ ${ }^{1}$ Department of Nutrition Science, Faculty of Medicine, Universitas Diponegoro, Jl. Prof. H. Soedarto, SH, Tembalang, \\ Semarang 1269, Indonesia \\ ${ }^{2}$ Center of Nutrition Research (CENURE), Jl. Prof. H. Soedarto SH, Tembalang, Semarang 1269, Indonesia \\ ${ }^{3}$ Department of Medicine Biology and Biochemistry, Faculty of Medicine, Universitas Diponegoro, Jl. Prof. H. Soedarto, SH, \\ Tembalang, Semarang 1269, Indonesia \\ Correspondence should be addressed to Diana N. Afifah; d.nurafifah.dna@fk.undip.ac.id
}

Received 18 February 2021; Revised 18 November 2021; Accepted 5 January 2022; Published 20 January 2022

Academic Editor: Teresa Zotta

Copyright (c) 2022 Diana N. Afifah et al. This is an open access article distributed under the Creative Commons Attribution License, which permits unrestricted use, distribution, and reproduction in any medium, provided the original work is properly cited.

\begin{abstract}
Fermented shrimp sausages are prepared spontaneously with Litopenaeus vannamei as raw material. Shrimp is one of the marine sources with rich chitosan as bioactive compounds, antioxidants, vitamin E, and probiotic lactic acid bacteria (LAB) produced by fermentation processes. This study aimed to analyze the variations in antioxidant activity, vitamin E content, total LAB, total pathogenic bacteria, $\mathrm{pH}$, and acceptability of shrimp sausage produced at different fermentation times. A completely randomized experimental design study was performed using four levels of exposure time, including control ( 0 days), 1, 2, and 3 days. The treatment was conducted spontaneously with $1.2 \%$ salt concentration, a drying temperature of $50^{\circ} \mathrm{C}$ for $3 \mathrm{~h}$, and fermentation at $35^{\circ} \mathrm{C}$. The evaluated parameters included the antioxidant activity measured with the radical 2,2-azino-bis (3-ethylbenzothiazoline6-sulphonic acid) method, vitamin E levels by high-performance liquid chromatography, total LAB with total plate count, and Escherichia coli bacteria by the most probable number method. Salmonella sp. and Staphylococcus aureus were estimated by the identification method. A pH meter was used to assess acidity, and hedonic organoleptic testing was performed for taste, aroma, color, and texture. The results show significant differences in antioxidant activity, vitamin E, and shrimp sausage acceptability at varied fermentation times $(p \leq 0.05)$. However, the best formulation was obtained with the first-day fermented shrimp sausage, as shown by its bioactive content and the level of acceptability.
\end{abstract}

\section{Introduction}

Coronary heart disease (CHD) is one of the major causes of death in Indonesia, and its prevalence showed an increase of $1.5 \%$ (15.259 people) in 2018 [1]. This estimate is expected to continuously rise to 23.3 million in 2030 [1]. High levels of cholesterol and low-density lipoproteins are linked as risk factors to CHD [2]. Consuming functional food products that are low in fat and rich in antioxidants can be an alternative diet choice for preventing CHD. Several marine organisms contain active compounds, such as antioxidants and anti-inflammatory compounds, which can be used as functional food for CHD prevention [3].

Shrimp is a marine product with rich bioactive antioxidant content in the form of chitosan, carotenoids, and monounsaturated fatty acids. The astaxanthin constituent has been identified as the most powerful antioxidant of xanthophyll. This condition is due to the carotenoid protein characteristics, which include the capability to reduce oxidative stress, protect from inflammation, and neutralize free radicals and oxidants [4]. Shrimps also contain vitamin E, which is assumed to confer protection on active compounds 
against the degradation process, with a possible value as an antioxidant [5]. The characteristics of bioactive contents indicate their potential application as raw material for fermented sausage for use as alternative functional food. However, seafood products are susceptible to spoilage due to mechanical, physiological, and microbiological influences. The fermentation process is carried out to enhance shelf life, resulting in a distinctive taste and increased product quality. The fermentation process can be possibly conducted spontaneously without the addition of any microorganisms [6]. This process involves protein and amino acid hydrolysis by enzymes of microbial origin, yielding bioactive peptides that are needed as antioxidants [7]. The lactic acid bacteria (LAB) produced demonstrate antioxidant effects that can inhibit free radicals and lower cholesterol levels [8,9]. The microorganisms generated can reduce the number of harmful pathogens present in the digestive tract upon ingestion and inhibit the growth of spoilage bacteria. This activity results from the ability of LAB to produce several metabolites, including organic acids (lactic and acetic acid), hydrogen peroxide, diacetyl, and bacteriocin. Furthermore, $\mathrm{LAB}$ are assumed to possess probiotic effects, maintaining the existence of intestinal microflora and increasing endurance $[10,11]$. The fermentation process increases the vitamin E content of shrimp sausages. This outcome results from the ability of LAB to produce primary and secondary metabolites following the hydrolysis of carbohydrates, fats, and proteins [12]. Moreover, the treatment reduces the water content due to the capability of added salt to attract hydrogen ions, subsequently causing a decline in the halfmaximal inhibitory concentration $\left(\mathrm{IC}_{50}\right)$ [13]. This effect occurs simultaneously with a high antioxidant activity, which is estimated to ensure the capture of free radicals [14]. Referencing the Indonesian National Standard, dry fermented sausages contain 30\%-40\% water content and have an $a_{w}$ value of $0.85-0.91$ [15].

Sausages are processed meat products that are ground, seasoned, and wrapped in sleeve. The ingredients added affect the bioactive and organoleptic compound composition. Marination of shrimp with lime juice aims to reduce the fishy scent, therefore improving the product aroma. In addition, adding 2\%-4\% salt further improves the flavor and inhibits the activity of spoilage microbes, thus facilitating the optimal growth of beneficial LAB [6]. The addition of sugar as a source of carbohydrates for microorganisms to produce lactic acid affects $\mathrm{pH}$, flavor, and storability of products [16]. Moreover, pepper and ginger enhance the taste and aroma of sausages, with ginger specifically increasing the antioxidant content [17]. In addition, garlic adds to the aroma and is useful as a bacteriostatic and antioxidant agent due to its inherent phenolic compounds and allicin [18]. The incorporated egg whites and oils serve as emulsifiers, whereas tapioca starch acts as a filler to improve the texture $[19,20]$. Furthermore, corn oil contains vitamin E (8\%) and can confer antioxidant effects; hence, its addition increases bioactivity [21]. The smoking and roasting processes affect the texture, chemical composition, and quality of the product, such as color, flavor, and juiciness [22]. Another study indicated that the interaction of $\mathrm{pH} 4$ and $50^{\circ} \mathrm{C}$ temperature for 10 min optimizes antioxidant activity and increases the concentration of solubility protein [23]. Therefore, the LAB generation during the fermentation process is implicated to reduce the $\mathrm{pH}$ matrix through the production of lactic acid from the fermentation of sugar [24]. The utilization of $5 \%$ liquid smoke improves the chemical, organoleptic, and microbiological quality and causes a simultaneous reduction in cholesterol [25]. Moreover, reducing the $\mathrm{pH}$ level of fermented sausages (4.5-5.0) inhibits the growth of pathogenic and spoilage bacteria. However, other studies suggest $4.8-5.4$ as the proper range [26]. The duration of fermentation also influences the amount of pathogenic microorganisms present in food products, with E. coli $(15 \%-20 \%)$, Salmonella sp. (1\%-5\%), and Staphylococcus aureus [25] being the most common in Indonesia. In addition, the existence of $E$. coli indicates the presence of other microorganisms capable of causing typhus, vomiting, and diarrhea. Salmonella sp. are usually found in foods with low environmental hygiene and closely related to the cleanliness of processing, storing, and serving. A poor setup facilitates the production of enterotoxins, which can initiate gastroenteritis and inflammation of the intestinal tract [27]. Based on this background, the study aimed to determine the differences in antioxidant activity, levels of vitamin $\mathrm{E}$, total $\mathrm{LAB}$, total pathogenic bacteria, acidity, and acceptance level of fermented shrimp sausage produced at varied fermentation durations.

\section{Materials and Methods}

This one-factor randomized complete design experimental study is classified into the field of food technology. The variables were tested at Undip Nutrition Science Laboratory, Integrated Services Unit of Undip Laboratory, Bogor Saraswanti Laboratory, and Health Laboratory of Central Java.

\subsection{Preparation Process of Fermented Shrimp Sausage.} The first step involved marinating 62.3\% Litopenaeus vannamei with $2 \%$ lime juice before grinding. Then, $12 \%$ ice cubes, $9.3 \%$ egg whites, $7.5 \%$ tapioca flour, $3.1 \%$ corn oil, $1.2 \%$ salt, $1.2 \%$ sugar, $0.6 \%$ garlic, $0.6 \%$ ginger, and $0.2 \%$ pepper were added, mixed sequentially, and poured into an edible sausage sleeve. The second step involved smoking and was conducted by soaking the shrimp sausage into a $5 \%$ liquid smoke solution for $30 \mathrm{~min}$. The shrimp was subsequently placed in an oven set at $50^{\circ} \mathrm{C}$ for $3 \mathrm{~h}$. The third stage involved fermenting the sausage from day 0 to day 3 [28] in an incubator (Esco ${ }^{8}$ model IFA-54-8, Esco Micro Pte. Ltd.) with a set temperature of $35^{\circ} \mathrm{C}[11,25]$. The products obtained on day 0 were used as a control.

2.2. Antioxidant Activity Test. Antioxidant activity was analyzed using the 2,2-azino-bis (3-ethylbenzothiazoline-6sulphonic acid) (ABTS) method [29]. This stock solution was created at a concentration of $7.4 \mathrm{mM}$. Potassium persulfate $(2.6 \mathrm{mM})$ was also formulated. Both solutions were mixed at a ratio of $1: 1(\mathrm{v} / \mathrm{v})$ and stored for $16-18 \mathrm{~h}$, followed by dilution to an absorbance level of $1.1 \pm 0.02$ units at a 
wavelength of $750 \mathrm{~nm}$. Subsequently, the samples were mixed with ABTS at a ratio of $1: 2(100 \mu \mathrm{L}: 200 \mu \mathrm{L})$ and stored at room temperature for $10 \mathrm{~min}$. The antioxidant activity was expressed as the inhibition percentage and calculated using the following formula.

Inhibition $(\%)=($ blank absorbance - sample absorbance) $/($ blank absorbance $) \times 100 \%$.

Inhibition $(\%)=\frac{\text { absorbance control }- \text { absorbance sample }}{\text { absorbance blanko }}$ $x 100 \%$.

The $\mathrm{IC}_{50}$ value can be calculated by the following formula:

$$
\mathrm{IC}_{50} \text { value }=50 \% \times \text { absorbance control. }
$$

2.3. Vitamin E Concentration Test. The vitamin E level was analyzed using high-performance liquid chromatography (HPLC) [30]. HPLC was performed on the Shimadzu Prominence system (Shimadzu Corporation, Kyoto, Japan) equipped with solvent delivery system LC-20AD, with a SIL20AC autosampler, DGU-AS online degasser, SPD-M20A DAD detector, CTO 20AC column oven, and CBM-20A communication module. Sample stock solutions were prepared by dissolving $100 \mathrm{~g}$ sample in $150 \mathrm{~mL} \mathrm{70 \%} \mathrm{ethanol,}$ followed by shaking with $350 \mathrm{~mL} n$-hexane solution. Then, the filtrate was separated using a separatory funnel. The oil part was collected and evaporated using a rotary evaporator vacuum regulated at a temperature of $50^{\circ} \mathrm{C}$. Moreover, the HPLC system was set to a stable baseline, and about 25-100 $\mu \mathrm{L}$ sample was injected and analyzed using a mobile phase with a flow rate of $1.5 \mathrm{~mL} / \mathrm{min}$ (normal phase).

2.4. $L A B$ Test. The total $\mathrm{LAB}$ were calculated using total plate count with three repetitions [24]. First, all the tools and materials to be used were sterilized in an autoclave at $121^{\circ} \mathrm{C}$ for $15 \mathrm{~min}$ at a pressure of $1 \mathrm{~atm}$ and used to create a liquid medium. Second, the samples were homogenized with distilled water. Third, a sterile test tube filled with $9 \mathrm{ml}$ distilled water was combined with $1 \mathrm{ml}$ suspension sample to achieve a homogenized dilution series. Fourth, the planting process was conducted by adding $1 \mathrm{ml}$ distilled water to the control Petri dish and $1 \mathrm{ml} 10^{-1}$ dilution suspension sample to the $10^{-1}$ Petri dish up to the last dilution. Then, the media were poured onto a Petri dish and incubated at $35^{\circ} \mathrm{C}-37^{\circ} \mathrm{C}$ for $24 \mathrm{~h}$ after solidification. The grown white or yellowish LAB colonies were subsequently collected and counted.

2.5. Pathogenic Bacterial Test. Pathogenic bacterial tests were performed to evaluate the presence of E. coli using the most probable number method [31]. S. aureus and Salmonella sp. were detected using the identification method with SNI-01-2332.2-2006. First, the liquid media were developed in an Erlenmeyer flask, followed by the sterilization of tools and materials by autoclaving at $121^{\circ} \mathrm{C}$ for $15-20 \mathrm{~min}$. Then,
$1 \mathrm{ml}$ sample was mixed with $9 \mathrm{ml}$ distilled water in the test tube up to a specific dilution value $\left(10^{-1}, 10^{-2}, 10^{-3}, 10^{-4}\right.$, $10^{-5}$, and $10^{-6}$ ). Therefore, $1 \mathrm{ml} 10^{-1}$ dilution sample was collected and transferred to a Petri dish containing the media before incubating at $35^{\circ} \mathrm{C}-37^{\circ} \mathrm{C}$ for $48 \mathrm{~h}$. The samples were then evaluated for microbial growth. The affirmative test of $E$. coli was carried out by observing medium color changes to red-green metallic sheen [32], whereas $S$. aureus and Salmonella sp. were confirmed positive if the color of the medium agar changed to red and yellow, respectively [33].

2.6. Acidity Test $(p H)$. The $\mathrm{pH}$ indicator/electrode was examined and calibrated with a solution of $\mathrm{pH}=7$ before rinsing with distilled water and subsequently dried. A slice of fermented shrimp sausage sample was assessed using calibrated $\mathrm{pH}$ electrodes placed on a glass, pending the attainment of stable and readable values.

2.7. Organoleptic Test. Organoleptic properties were evaluated in 30 respondents using a hedonic test questionnaire. This tool examined the aspects of color, aroma, texture, and taste with four scales: $1=$ worse, 2 =bad, 3 =good, and 4 =best [34]. The best formulation was selected using a weighting technique considering the hedonic test attributes (color, aroma, texture, and taste) and the bioactive component.

2.8. Data Analysis. Data analysis was performed using SPSS 25.0 software for Windows with a $p$ value $\leq 0.05$, whereas normality was evaluated using the Shapiro-Wilk test for values $<50$. The antioxidant activity, vitamin E levels, and acidity $(\mathrm{pH})$ were tested using analysis of variance. Meanwhile, Kruskal-Wallis test was adopted in the assessment of LAB, pathogenic bacteria, and the level of acceptance.

\section{Results and Discussion}

3.1. Antioxidant Activity. Table 1 presents the shrimp sausages produced at different fermentation times, demonstrating variation in the mean percentage of inhibition $(p<0.05)$. In addition, the highest value was obtained on the 3rd day at $42.09 \%$ per $0.1 \mathrm{~g}$, whereas the least value was recorded on day 0 (control) at $23.93 \%$ per $0.1 \mathrm{~g}$.

Antioxidant activity is the capability for oxidants to capture free radicals, and a high level indicates the need for less food to ensure optimal acquisition [35]. The results of statistical tests showed differences in the average percent inhibition value $(p=0.05)$ and $\mathrm{IC}_{50}(p=0.024)$. In addition, the highest antioxidant activity was measured in shrimp sausages treated with 3-day fermentation time. This sample demonstrated a percentage inhibition value of $42.09 \%$ per $0.1 \mathrm{~g}$ and an $\mathrm{IC}_{50}$ value of $1.161 \mathrm{ppm}$ and was hence classified in the very powerful category [36].

The fermentation process can produce probiotic LAB that have antihypertensive and cholesterol-lowering effects and inhibit the growth of pathogen bacteria $[8,9]$. These activities are also influenced by the addition of ginger, garlic, 
TABLE 1: Results of the inhibition percentage (\%) of fermented shrimp sausages at different fermentation times.

\begin{tabular}{lc}
\hline Duration & Inhibition $(\%)$ \\
\hline Fresh prawn & $17.36 \pm 2.746 *$ \\
0 days & $23.93 \pm 2.927 *$ \\
1 day & $26.57 \pm 3.935 *$ \\
2 days & $34.32 \pm 4.956$ \\
3 days & $42.09 \pm 5.994 *$ \\
& $p=0.005^{\mathrm{a}}$ \\
\hline
\end{tabular}

* Significance $<0.05 ;{ }^{a}$ ANOVA: analysis of variance.

and corn oils containing phenolic compounds, alongside the sausage preparation process before fermentation at $50^{\circ} \mathrm{C}$. Furthermore, the smoking treatment using liquid smoke has been implicated due to the phenolic compounds, organic acids, and carbonyl content, which are assumed to serve as flavor, bacteriostatic, and antioxidant agents [37].

3.2. $I_{50}$ Value. Table 2 presents the average $\mathrm{IC}_{50}$ value of shrimp sausages produced at different fermentation durations which varied significantly $(p<0.05)$. This finding is congruent with that of previous studies, including the report on kombucha fermentation for $0,1,2$, and 3 days, in which $\mathrm{IC}_{50}$ increased from $120 \mathrm{ppm}$ to $54.46 \mathrm{ppm}$ [38]. Furthermore, the best outcome was recorded on the third day at $1.161 \mathrm{ppm}$, whereas the least $(1.849 \mathrm{ppm})$ was observed on day 0 (control). Moreover, food is considered to possess very strong antioxidant characteristics at $\mathrm{IC}_{50}<10 \mathrm{ppm}$ [39].

3.3. Vitamin E Level. Table 3 presents the average levels of vitamin $\mathrm{E}$, which differed between shrimp sausages produced at different fermentation durations $(p<0.05)$. In addition, the highest result at $4.985 \mathrm{mg} / 100 \mathrm{~g}$ was recorded on the third day, whereas the least $(2.685 \mathrm{mg} / 100 \mathrm{~g})$ was obtained on day 0 (control).

Vitamin $\mathrm{E}$ is one of the compounds contained in shrimp; it is characterized by a phenol group on the 6-chromanol ring and has a useful function of protecting in attacking free radicals [40]. Processed foods are considered a source of vitamin $\mathrm{E}$, possessing a minimum of $15 \%$ nutrition label reference in the solid form or $7.5 \%$ nutrition label reference in the liquid form. Meanwhile, the potential for high content is considered in cases where over twice the amount is present in the source [41]. During the fermentation process, LAB produce metabolites from the hydrolysis of carbohydrates, fats, and proteins, including the primary forms from small compounds, e g., vitamins and minerals, and secondary forms, e g., antibiotics, enzyme inhibitors, and growth boosters [12]. Previous studies on gude seed tempe have attributed the increase in the content of dissolved proteins, vitamins, and available minerals to the presence of molds. These microorganisms grow on the sample and hydrolyze intrinsic complex compounds into simpler forms [42, 43]. The increase in levels of vitamin E present in shrimp sausages is also caused by the addition of vitamin E (8\%)containing corn oil, which acts as antioxidants by inhibiting free radicals.
TABLE 2: Results of $\mathrm{IC}_{50}$ (ppm) of fermented shrimp sausages at different fermentation times.

\begin{tabular}{lc}
\hline Duration & $\mathrm{IC}_{50}$ value $(\mathrm{ppm})$ \\
\hline Fresh shrimp & $2.99 \pm 0.227 *$ \\
0 days & $1.849 \pm 0.189 *$ \\
1 day & $1.655 \pm 0.276$ \\
2 days & $1.597 \pm 0.256$ \\
3 days & $1.161 \pm 0.069 *$ \\
& $p=0.024^{\mathrm{a}}$ \\
\hline
\end{tabular}

* Significance $<0.05 ;{ }^{\text {a } A N O V A}$ : analysis of variance.

TABLE 3: Results of the vitamin E level (mg/dl) of fermented shrimp sausages at different fermentation times.

\begin{tabular}{lc}
\hline Duration & Vitamin E levels $(\mathrm{mg} / 100 \mathrm{~g})$ \\
\hline Fresh shrimp & $1.515 \pm 0.007 *$ \\
0 days & $2.685 \pm 0.007 *$ \\
1 day & $3.355 \pm 0.007 *$ \\
2 days & $4.090 \pm 0.000 *$ \\
3 days & $4.985 \pm 0.021 *$ \\
& $p<0.001^{\mathrm{a}}$ \\
\hline
\end{tabular}

$*$ Significance $<0.05$; ${ }^{a}$ ANOVA: analysis of variance.

3.4. Total $L A B$. Table 4 shows the average difference in the total LAB of shrimp sausages treated with varied fermentation durations $(p<0.05)$. The highest value $\left(13.88 \times 10^{9} \mathrm{CFU} / \mathrm{ml}\right)$ was recorded on day 3 , where the least $\left(0.429 \times 10^{9} \mathrm{CFU} / \mathrm{ml}\right)$ was observed on day 0 (control).

The total LAB were positively influenced by the fermentation duration. This finding is an indicator of the ability for growth in the initial phase, prompting adjustments to the inhabiting substrate. Furthermore, this condition causes cell multiplication and active transport processes, in which microorganisms maintain their $\mathrm{pH}$ in the cytoplasm by the $\mathrm{pH}$ homeostasis mechanism based on the transport protons across the cell membrane [44]. The anaerobic bacteria, during the fermentation process, perform $\mathrm{H}^{+}$transport through molecules of $\mathrm{H}^{+}$-ATPase with the use of energy; in this way, the main product of lactic acid contributes to maintain acid-base balance [44]. In addition, a high concentration of LAB was observed alongside the extended fermentation duration, with a tendency to overhaul the nutrients contained in the substrate. This phenomenon possibly allows the accumulation of organic acids in high amounts [45].

The initial phase of fermentation features the growth pattern adaptation of LAB. The first-day fermented shrimp sausage formulation showed an increase in total bacteria, resulting from the dominant activity of the microorganism to convert carbohydrates into lactic acid. This phase is classified as logarithmic, at which the bacteria quickly and constantly experienced a rapid growth rate. Certain species of bacteria extremely multiply due to the content of nutrients, water activity $\left(a_{w}\right), \mathrm{pH}$ value, storage temperature, composition atmosphere, physical/chemical treatment during processing, and the specific growth rate of the bacteria themselves [44]. The concentration of alcohol and $\mathrm{CO}_{2}$ produced increased, possibly up to levels toxic for the 
TABLE 4: Result of total LAB of fermented shrimp sausages at different fermentation times.

\begin{tabular}{lc}
\hline Duration & Total LAB $\left(\times 10^{9} \mathrm{CFU} / \mathrm{ml}\right)$ \\
\hline 0 days & $0.429 \pm 0.422$ \\
1 day & $5.055 \pm 4.879$ \\
2 days & $8.437 \pm 8.676$ \\
3 days & $13.88 \pm 9.988$ \\
& $p=0.048 *^{\mathrm{b}}$ \\
\hline
\end{tabular}

$*$ Significance $<0.05$; ${ }^{\mathrm{b}}$ Kruskal-Wallis test.

survival of microbes [46]. In addition, an increase in the LAB population caused a decline in $\mathrm{pH}$ and an increase in acidity. This condition is unsuitable for certain LAB, e g., Lactobacillus bulgaricus, Streptococcus thermophilus, and Lactobacillus acidophilus, thus leading to bacterial death.

3.5. Pathogenic Bacteria. The identification test results from days $0,1,2$, and 3 showed negative/25 g for Salmonella sp., $<3 / \mathrm{g}$ in the case of Escherichia coli, and $1 \times 10^{2} \mathrm{CFU} / \mathrm{g}$ for Staphylococcus aureus. These findings are congruent with the Indonesian National Standard for food and beverages. The cumulation of the large amount of LAB in the product can inhibit pathogenic bacteria. This result is due to the high bactericidal effect at low $\mathrm{pH}$ [47]. In addition, different types of $L A B$ produced varied inhibition and activities due to the influence of metabolite components produced. Acetic acid, formic acid, succinic acid, ethanol, hydrogen peroxide, and diacetyl were also generated by LAB action. These products are antagonistic and can inhibit the growth of other bacteria [48].

3.6. Acidity Level $(\mathrm{pH})$. Table 5 presents the average $\mathrm{pH}$ level of shrimp sausages with differences in fermentation durations $(p<0.05)$. The highest value was observed on day 0 (6.6), whereas the least was recorded on day 3 (5.71). The fermentation duration affected the extent of $\mathrm{pH}$ decline, resulting from the conversion of glucose to lactic acid. Fermented catfish sausage by smoking for $30 \mathrm{~min}$ at a temperature of $30^{\circ} \mathrm{C}$ can increase LAB levels and lower $\mathrm{pH}$ [28]. Therefore, low values alongside elevated concentrations of lactic acid further inhibit pathogenic bacterial growth [49]. The recommended $\mathrm{pH}$ value for fermented sausage is between 4.8 and 5.4 [50].

3.7. Organoleptic Test. Differences were observed in shrimp sausage color, following the variations in fermentation duration $(p<0.05)$ presented in Table 6. In addition, the highest intensity was observed on day 0 and the least on day 3. Color changes were also observed during storage. This finding is attributed to the naturally existing pigments in food, caramelization, Maillard reactions, and the interaction between organic compounds and air [51]. Moreover, prolonged fermentation duration increased the darker color of fermented shrimp sausage. This phenomenon was due to the presence of $\mathrm{H}_{2} \mathrm{O}_{2}$ produced by microorganisms through aerobic metabolism. Furthermore, the reactive compound formed is assumed to cause a decline in the red
TABLE 5: Results of the acidity value $(\mathrm{pH})$ of fermented shrimp sausages at different fermentation times.

\begin{tabular}{lc}
\hline Duration & $\mathrm{pH}$ value \\
\hline 0 days & $6.600 \pm 0.327$ \\
1 day & $6.290 \pm 0.209$ \\
2 days & $6.027 \pm 0.347$ \\
3 days & $5.710 \pm 0.471^{*}$ \\
& $p=0.022^{\mathrm{a}}$ \\
\hline
\end{tabular}

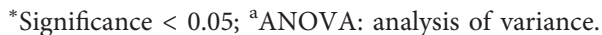

pigmentation, following the formation of brown metmyoglobin [52]. The smoking process has also been implicated in color changes, resulting from the smoke absorption capacity of the product surface, as evidenced by a reaction between carbonyl groups. This condition further leads to a brownish pigmentation in sausages [53].

A significant difference was observed between the aroma of shrimp sausages prepared at varied fermentation durations $(p<0.05)$. The highest level of aroma was observed on day 0 and the lowest on day 2. Moreover, Maillard reactions occurred following an interaction between amino groups and reducing sugars. This phenomenon was assumed to produce volatile compounds during the fermentation process [52-54]. Therefore, a long treatment duration causes a decline in $\mathrm{pH}$, alongside an increase in the amount of lactic acid produced from LAB metabolism. This condition further stimulates the aroma of fermented shrimp sausages to be more acidic [55].

The texture of shrimp sausages differed across the treatments with varied durations of fermentation $(p<0.05)$. In addition, samples obtained on day 1 demonstrated the best texture, whereas the poorest result was recorded on day 3. A chewy texture was caused by the presence of amylose and amylopectin in tapioca flour [41]. This shrinking is affiliated with the fermentation duration and assumed to play a role in hardening the texture. In addition, this parameter is influenced by product $\mathrm{pH}$, given that low values are implicated in the high tendency for meat shrinkage [41]. Furthermore, acid conditions during the fermentation process also aid in texture formation due to meat protein coagulation and in color formation through the reactions of nitrite and nitrogen monoxide with myoglobin [44].

The flavor of shrimp sausages varied at different fermentation durations $(p<0.05)$. Furthermore, the highest flavor acceptance was observed on day 0 and the lowest on day 2. Flavor is a stimulus of food, especially by the sense of taste and odor [41]. The fermentation process is characterized by the degradation of compounds, including the conversion of proteins into amino acids and peptides. These activities cause specific flavors [41]. In addition, long processes and the decline in $\mathrm{pH}$ instigate a rise in acid levels. The increased amount of lactic acid generated leads to high acidity in the taste of sausages.

3.8. Selected Formula Weighting. Tables 7 and 8 present the weighting results of hedonic test attributed to the indicators of color, aroma, texture, and taste. $25 \%$ weighting on each 
TABLE 6: Results of the organoleptic analysis of fermented shrimp sausages at different fermentation times.

\begin{tabular}{lcccc}
\hline \multirow{2}{*}{ Duration } & \multicolumn{2}{c}{ Categories (mean \pm SD) } & Taste \\
& Color & Aroma & Texture & $2.47 \pm 0.86^{\mathrm{a}}$ \\
0 days & $3.20 \pm 0.76^{\mathrm{a}}$ & $2.97 \pm 0.99^{\mathrm{a}}$ & $2.30 \pm 0.87^{\mathrm{a}}$ & 2.73 \\
1 day & $2.73 \pm 0.82^{\mathrm{b}}$ & $2.73 \pm 0.94^{\mathrm{b}}$ & $2.57 \pm 0.77^{\mathrm{a}}$ & $1.97 \pm 0.76^{\mathrm{a}}$ \\
2 days & $2.63 \pm 0.66^{\mathrm{b}}$ & $1.60 \pm 0.81^{\mathrm{c}}$ & $1.83 \pm 0.69^{\mathrm{b}}$ & $1.57 \pm 0.72^{\mathrm{b}}$ \\
3 days & $2.00 \pm 0.94^{\mathrm{c}}$ & $1.90 \pm 0.88^{\mathrm{d}}$ & $1.50 \pm 0.73^{\mathrm{c}}$ & $2.17 \pm 1.05^{\mathrm{a}}$ \\
& $p<0.001 *$ & $p<0.001 *$ & $p<0.001 *$ & $p=0.001 *$ \\
\hline
\end{tabular}

Different superscript letters (a, b, c, and d) show significant differences between groups; $*$ Kruskal-Wallis test.

TABLE 7: Results of weighting hedonic test.

\begin{tabular}{lcccc}
\hline Indicator & Day 0 (F0/control) & Day 1 (F1) & Day 2 (F2) & 0.65 \\
\hline Color (25\%) & 0.8 & 0.68 & 0.4 & 0.5 \\
Aroma (25\%) & 0.74 & 0.68 & 0.45 & 0.47 \\
Texture (25\%) & 0.57 & 0.64 & 0.39 & 0.37 \\
Flavor (25\%) & 0.61 & 0.49 & 1.89 & 0.54 \\
Total & 2.72 & 2.49 & Day & 1.88 \\
\hline
\end{tabular}

TABLE 8: Determination of selected formulation score.

\begin{tabular}{lccccccc}
\hline Treatment & Hedonic test (25\%) & Score & Antioxidant test $(25 \%)$ & Score & Vitamin E test $(25 \%)$ & Score & Total \\
\hline F0 & 1 & 0.25 & 1 & 0.25 & 1 & 0.25 \\
F1 & 4 & 1 & 2 & 0.5 & 0.75 \\
F2 & 3 & 0.75 & 3 & 0.75 & 2 & 0.5 \\
F3 & 2 & 0.5 & 4 & 1 & 4 & 2 \\
\hline
\end{tabular}

indicator, including color, aroma, texture, and taste, was provided on the fermented shrimp sausages. The first rank was obtained by treatment samples for day 0 , followed by F1, F2, and F3. Therefore, F1 was selected because F0 was not fermented.

Based on the weighting results, the third-day fermented shrimp sausage formulation (F3) was selected because of its bioactive content. However, its hedonic test score was the lowest and was not favored by panelists. Therefore, F1 was selected considering the bioactive constituents and the level of consumer acceptance. The hedonic quality assessment showed the panelists an acceptance level of 1.97, which indicates a low preference, whereas the acceptance values of color, aroma, and texture were $2.73,2.73$, and 2.57 , respectively. Therefore, the first-day fermented shrimp sausage (F1) was selected, considering the bioactive content and the level of consumer acceptance.

\section{Conclusions}

Significant differences were observed in the mean antioxidant activity, levels of vitamin $\mathrm{E}$, total LAB, acidity value $(\mathrm{pH})$, and acceptance level of shrimp sausages treated with different fermentation times $(0,1,2$, and 3 days $)$ at $p \leq 0.05$. Overall, different fermentation times played role changes in the bioactive content and the quality characteristics of fermented sausages. A long treatment duration causes a decline in $\mathrm{pH}$, alongside an increase in the bioactive content. However, the best formulation was obtained with the firstday fermented shrimp sausage, as shown by its bioactive content and the level of acceptability. It scored of the total weighting hedonic test at 2.49 with $26.57 \%$ antioxidant activity, $1.655 \mathrm{ppm} \quad \mathrm{IC}_{50}, \quad 3.355 \mathrm{mg} / 100 \mathrm{~g}$ vitamin $\mathrm{E}$, $5.055 \times 10^{9} \mathrm{CFU} / \mathrm{ml}$ total $\mathrm{LAB}$, and $6.29 \mathrm{pH}$.

\section{Data Availability}

The fermented shrimp sausage's ingredients, inhibition percentage $(\%), \mathrm{IC}_{50}(\mathrm{ppm})$, vitamin E level $(\mathrm{mg} / \mathrm{dl})$, total $\mathrm{LAB}\left(10^{9} \mathrm{CFU} / \mathrm{ml}\right)$, acidity value $(\mathrm{pH})$, organoleptic analysis, and weighting hedonic test of fermented shrimp sausages at different fermentation times used to support the findings of this study are included within the article.

\section{Conflicts of Interest}

The authors declare that there are no conflicts of interest regarding the publication of this paper.

\section{Acknowledgments}

The authors are grateful to the Directorate of Research and Community Service of the Directorate General of Research and Development Strengthening, Ministry of Research, Technology and Higher Education for funding this study through Higher Education Leading Basic Research Scheme with Contract no. 257-39/UN7.P4.3/PP/2019.

\section{References}

[1] Kementerian Kesehatan Republik Indonesia, Riset Kesehatan Dasar (Riskedsas), Kementrian Kesehatan, Jakarta, 2018. 
[2] J. L. Goldstein and M. S. Brown, "A century of cholesterol and coronaries: from plaques to genes to statins," Cell, vol. 161, no. 1, pp. 161-172, 2015.

[3] L. K. Darusman, I. Batubara, T. Mitsunaga, M. Rahminiwat, E. Djauhari, and K. Yamauchi, "Tyrosinase kinetic inhibition of active compounds from intsia palembanica," Research Journal of Medicinal Plant, vol. 6, no. 8, pp. 615-620, 2012.

[4] S. Klomklao, S. Benjakul, W. Visessanguan, H. Kishimura, and B. K. Simpson, "Extraction of carotenoprotein from black tiger shrimp shells with the aid of bluefish trypsin," Journal of Food Biochemistry, vol. 33, no. 2, pp. 201-217, 2009.

[5] R. Youngson, Antioksidan: Manfaat Vitamin C Dan E Bagi Kesehatan, Archan, Jakarta, 2005.

[6] L. O. Anwar, L. Hardjito, and Desniar, "Fermentation of Tambelo and its product characteristics," JPHPI, vol. 17, no. 3, pp. 254-262, 2014.

[7] C.-T. Chang, C.-K. Hsu, S.-T. Chou, Y.-C. Chen, F.-S. Huang, and Y.-C. Chung, "Effect of fermentation time on the antioxidant activities of tempeh prepared from fermented soybean usingRhizopus oligosporus," International Journal of Food Science and Technology, vol. 44, no. 4, pp. 799-806, 2009.

[8] M. Bosch, M. C. Fuentes, S. Audivert, M. A. Bonachera, S. Peiró, and J. Cuñé, "Lactobacillus plantarum CECT 7527, 7528 and 7529: probiotic candidates to reduce cholesterol levels," Journal of the Science of Food and Agriculture, vol. 94, no. 4, pp. 803-809, 2014.

[9] Y. Suzuki, M. Kosaka, K. Shindo, T. Kawasumi, H. KimotoNira, and C. Suzuki, "Identification of antioxidants produced byLactobacillus plantarum," Bioscience Biotechnology and Biochemistry, vol. 77, no. 6, pp. 1299-1302, 2013.

[10] H. Yuguchi, T. Goto, and S. Okonogi, "Fermented milk, lactic drinks, and intestinal mikroflora," Function of Fermented Milk: Challenge for the Health Science, Elsevier Applied Science, New York, 1992.

[11] A. N. Khoyrun and W. K. Agustin, "The effect of smoking time and fermentation on the fermented sausage catfish (Clarias gariepinus) quality," Jurnal Pangan dan Agroindustri, vol. 4, no. 1, pp. 367-376, 2016.

[12] S. Maryam, "Potensi tempe kacang hijau (vigna radiata L) hasil fermentasi menggunakan inokulum tradisional sebagai pangan fungsional," JST (Jurnal Sains dan Teknologi), vol. 4, no. 2, pp. 639-646, 2015.

[13] D. A. Anggorowati, G. Priandini, and T. Thufail, "Potensi daun alpukat (persea americana miller) sebagai minuman teh herbal yang kaya antioksidan," Journal of Industry and Innovation.vol. 6, no. 1, pp. 1-7, 2016.

[14] A. Kusbandari and H. Susanti, "Kandungan beta karoten dan aktivitas penangkapan radikal bebas terhadap dpph $(1,1-$ difenil 2-pikrihydrazil) ekstrak buah blewah (Cucumis melo var. cantalupensis L) secara spektrofotometri uv-visibel," Journal of Pharmaceutical Sciences and Community, vol. 14, no. 1, pp. 37-42, 2017.

[15] T. Sopandi Wardah, Mikrobiologi Pangan, Andi, Yogyakarta, 2013.

[16] I. Gianti and H. Evanuarini, "The effect of sugar addition and time of storage on physical quality of fermented milk," Jurnal Ilmu Produksi dan Teknologi Hasil Peternakan, vol. 6, no. 1, pp. 28-33, 2011.

[17] M. Arif, "Tamrin, and syukri, "effect of addition of carrageenan and ginger on organoleptic and physicochemical properties of chocolate bar," Jurnal Sains dan Teknologi Pangan, vol. 2, no. 2, pp. 394-404, 2017.

[18] C. Wilson and S. Droby, Microbial Food Contamination, CRC, London, 2001.
[19] D. Wulandari, N. Komar, and S. H. Sumarlan, "Perekayasaan pangan berbasis produk lokal Indonesia (studi kasus sosis berbahan baku tempe kedelai)," Jurnal. Bioproses Komod. Trop.vol. 1, no. 2, pp. 73-82, 2013.

[20] R. O. Sujarwanta, "Kualitas sosis daging sapi yang difortifikasi dengan minyak ikan kod dan minyak jagung dan diproses menggunakan metode pemasakan yang berbeda," Buletin Peternakan, vol. 40, no. 1, p. 47, 2016.

[21] M. S. Ibrahim, G. Rasool, S. Hussain, and Z. Alam, "Effect of corn oil on the quality characteristics of mayonnaise," Pakistan Journal of Nutrition, vol. 12, no. 9, pp. 860-864, 2013.

[22] P. Duma-Kocan, M. Rudy, M. Gil, and R. Stanisławczyk, "The influence of temperature differences in smoking chamber and furnace and smoking time on the quality of medium-ground sausages," Molecules, vol. 25, no. 23, 23 pages, Article ID 5515, 2020.

[23] E. Susanto, D. Rosyidi, and L. Eka Radiat, "Effect of pH and temperature on characteristics and antioxidant activity of chicken feet protein," The Asian Journal of Animal Science, vol. 12, no. 1, pp. 9-15, 2017.

[24] Y. Liu, Z. Wan, K. W. Yohannes et al., "Functional characteristics of Lactobacillus and yeast single starter cultures in the ripening process of dry fermented sausage," Frontiers in Microbiology, vol. 11, pp. 1-15, 2021.

[25] P. Lukman, B. R. Handayani, and S. Saloko, The Effect of Liquid Smoke Powder Concentration on the Quality and Shelf Life of Dry Lung, Universitas Mataram, Mataram, Indonesia, 2017.

[26] O. Martinez, J. Salmerón, M. D. Guillén, and C. Casas, "Textural and physicochemical changes in salmon (Salmo salar) treated with commercial liquid smoke flavourings," Food Chemistry, vol. 100, no. 2, pp. 498-503, 2007.

[27] P Widyastuti and B. Makanan, Fokus Pendidikan Kesehatan, (Andri Hartono, Penerjemah), Penerbit Buku Kedokteran ECG, Jakarta, 2006.

[28] H. Nursyam, "Pengolahan sosis fermentasi ikan tuna (Thunnus sp.) menggunakan kultur starter Lactobacillus plantarum terhadap nilai $\mathrm{pH}$, total asam, $\mathrm{N}$-total, dan N-amino," Jurnal ilmiah perikanan dan kelautan, vol. 3, no. 2, pp. 221-228, 2011.

[29] E. Rodrigues, N. Poerner, I. I. Rockenbach, L. V. Gonzaga, C. R. Mendes, and R. Fett, "Phenolic compounds and antioxidant activity of blueberry cultivars grown in Brazil," Food Science and Technology, vol. 31, no. 4, pp. 911-917, 2011.

[30] Z. Xu, "Analysis of tocopherols and tocotrienols," Handbook of Food Analytical Chemistry, vol. 1, no. 2, pp. 479-490, 2005.

[31] H. Kodaka, M. Saito, and H. Matsuoka, "Evaluation of a new Most-Probable-Number (MPN) dilution plate method for the enumeration of Escherichia coli in water samples," Biocontrol Science, vol. 14, no. 3, pp. 123-126, 2009.

[32] A. Antony, M. Paul, R. Silvester et al., "Comparative evaluation of EMB agar and hicrome E. coli agar for differentiation of green metallic sheen producing non E. Coli and typical E. Coli colonies from food and environmental samples," Journal of Pure and Applied Microbiology, vol. 10, no. 4, pp. 2863-2870, 2016.

[33] M. J. Zimbro, D. A. Power, S. M. Miller, G. E. Wilson, and J. A. Johnson, Difco \& BBL Manual: Manual of Microbiological Culture Media, Difco Laboratories, Maryland, 2009.

[34] M. C. Mervina and S. Marliyati, "Formulasi biskuit dengan substitusi tepung ikan lele dumbo (Clarias gariepinus) dan isolat protein kedelai (Glycine max) sebagai makanan potensial untuk anak balita gizi kurang," Jurnal Teknologi dan Industri Pangan, vol. 23, no. 1, pp. 9-16, 2012. 
[35] L. Malangngi, M. Sangi, and J. Paendong, "Penentuan kandungan tanin dan uji aktivitas antioksidan ekstrak biji buah alpukat (Persea americana mill.)," Jurnal MIPA, vol. 1, no. 1, p. 5,2012 .

[36] M. Philip, "The use of the stable free radical diphenylpicrylhydrazyl (DPPH) for estimating anti-oxidant activity," Songklanakarin Journal of Science and Technology, vol. 26, no. May, pp. 1-10, 2004.

[37] S. Saloko, P. Darmadji, B. Setiaji, and Y. Pranoto, "Antioxidative and antimicrobial activities of liquid smoke nanocapsules using chitosan and maltodextrin and its application on tuna fish preservation," Food Bioscience, vol. 7, pp. 71-79, 2014.

[38] N. Rupadani, N. Susanti, and N. Leliqia, "Uji aktivitas antioksidan minuman kombucha lokal di Bali dengan substrak gambir," Journal of Public Administration Research and Theory, vol. 1, no. 2, pp. 131-139, 2011.

[39] S. Phongpaichit, J. Nikom, N. Rungjindamai et al., "Biological activities of extracts from endophytic fungi isolated fromGarciniaplants," FEMS Immunology and Medical Microbiology, vol. 51, no. 3, pp. 517-525, 2007.

[40] S. Li, G. Chen, C. Zhang, M. Wu, S. Wu, and Q. Liu, "Research progress of natural antioxidants in foods for the treatment of diseases," Food Science and Human Wellness, vol. 3, no. 3-4, pp. 110-116, 2014.

[41] R. I. Bpom, Pengawasan Klaim Dalam Label Dan Iklan Pangan Olahan: Peraturan Kepala Badan Pengawasan Obat Dan Makanan, ", 2011.

[42] M. J. R. Nout and J. L. Kiers, "Tempe fermentation, innovation and functionality: update into the third millenium," Journal of Applied Microbiology, vol. 98, no. 4, pp. 789-805, 2005.

[43] W. Shurtleff and A. Aoyagi, The Book of Miso: Savory, HighProtein, Seasoning, Ten Speed Press, New York, 2001.

[44] F. Toldrá, Handbook of Fermented Meat and Poultry, Blackwell Publishing, NJ, USA, 2008.

[45] Y. Yunus and E. Zubaidah, "The effect of sucrose concentration and fermentation time to viability of Lactobacillus casei during frozen storage for velva from ambon banana," Jurnal Pangan dan Agroindustri, vol. 3, no. 2, pp. 303-312, 2015.

[46] E. R. Farnworth and I. Mainville, "Kefir: a fermented milk product," in Hand book of Fermented Functional Foods, pp. 77-112, London, UK, CRC Press, 2003.

[47] B. Ray, Fundamental food microbiology, CRC Press, vol. 97, CRC Press, Boca Raton, Third edition1 page, Boca Raton, 2004.

[48] J. Nurhajati, Atira, I. N. P. Aryantha, and D. G. Kadek Indah, "The curative action of Lactobacillus plantarum FNCC 226 to Saprolegnia parasitica A3 on catfish (pangasius hypophthalamus sauvage)," International Food Research Journal, vol. 19, no. 4, pp. 1723-1727, 2012.

[49] S. D. Todorov, "Bacteriocins from Lactobacillus plantarum production, genetic organization and mode of action: produção, organização genética e modo de ação," Brazilian Journal of Microbiology, vol. 40, no. 2, pp. 209-221, 2009.

[50] S. Ahmad and Q. Nawab, "Temperature of fermentation," Journal of Meat Science Technology, vol. 2, no. 3, pp. 51-62, 2014.

[51] Susanti, Studi Keamanan Pangan dan Karakteristik Sifat Fisik dan Kimia serta Organoleptik 9 Merek Sosis Sapi yang Beredar di Pasar Swalayan Kodya Malang (Kajian Kadar Nitrit dan Jenis Pewarna Sintetis), Universitas Brawijaya, Malang, Indonesia, 2001.
[52] I. I. Arief, T. Suryati, and R. R. A. Maheswari, "Sifat fisik daging sapi dark firm dry (DFD) hasil fermentasi bakteri asam laktat Lactobacillus plantarum," Media Peternak.vol. 29, no. 2, pp. 76-82, 2006.

[53] N. Lawrie, Ilmu Daging, Universitas Indonesia Press, Jakarta, 5th ed. edition, 2003.

[54] N. S. Antara, I. N. Sujaya, A. Yokota, K. Asano, W. R. Aryanta, and F. Tomita, "Identification and succession of lactic acid bacteria during fermentation of 'urutan', a Balinese indigenous fermented sausage," World Journal of Microbiology and Biotechnology, vol. 18, no. 3, pp. 255-262, 2002.

[55] K. A. Buckle, R. Edwards, E. Fleet, and M. Wotton, Ilmu Pangan, Universitas Indonesia Press, Jakarta, 2010. 